\title{
The Effect of the Psycho-Education Program for Increasing Mathematics Course Achievement in Tenth-Grade Students*
}

\author{
Research Article \\ Demet SISLI ${ }^{1}$, Sabahattin CAM ${ }^{2}$ \\ ${ }^{1}$ Psychological Counselor, Ministry of National Education, Adana, Turkey, ORCID: 0000-0002-4651-4221 \\ ${ }^{2}$ Cukurova University, Faculty of Education, Adana, Turkey, ORCID: 0000-0003-2262-6357
}

To cite this article: Sisli, D., \& Cam, S. (2021). The effect of the psycho-education program for increasing mathematics course achievement in tenth-grade students, International Online Journal of Educational Sciences, 13(2), 478-491.

\begin{abstract}
ARTICLE INFO
ABSTRACT

Article History:

The aim of the study is to examine the effect of the cognitive-behavioral approach-based psychoeducation program supported by the follow-up study of the behaviors of efficient course

Received:16.06.2020 studying given to tenth-grade students who have failed the mathematics course and have a

Available negative perception of the course and the teacher of the course on students' perceptions of

online:03.05.2021 mathematics course achievement, the course, and the teacher of the course. The research is a quasi-experimental study and was conducted with a total of 30 tenth-grade students studying in an official academic high school in Adana, including 15 students (8F-7M) in the experimental group and 15 students $(8 \mathrm{~F}-7 \mathrm{M})$ in the control group. In the study, data were collected using the Attitude Towards the Mathematics Course Scale, Attitude Towards the Teacher Scale, and the tests prepared by the teacher to measure mathematics course achievement in achievement measurement. The data analysis was conducted using the SPSS 22.0 package program, and in the analysis, the $2 \times 2$ mixed-design analysis of variance, the covariance analysis in which pre-test scores were included in the analysis as a covariate, and variance analysis techniques for repeated measurements were used. According to the results obtained, it was observed that the mathematics course achievement scores of the experimental group students who were given the psycho-education program supported by the follow-up study of efficient course studying behaviors increased in comparison with the control group students to whom the education was not given. Furthermore, it was found that the attitudes towards the mathematics course and the teacher were positively affected in the experimental group students to whom the experimental process was applied. The findings of the research are discussed in accordence with the relevent literature. Application on the subjects and recommendations for new research have been presented.
\end{abstract}

(C) 2021 IOJES. All rights reserved

\footnotetext{
* This study was produced from a master's thesis with the same name prepared by Demet şişLİ at Ç. Ü. Social Sciences Institute under the consultancy of Assist. Prof. Dr. Sabahattin Çam and presented as an oral presentationat the $21^{\text {st }}$ International Psychological Counseling and Guidance Congress.

${ }^{1}$ Corresponding author's address: Cukurova University

Telephone: +905426566164

e-mail: sabahcam@cu.edu.tr

DOI: https://doi.org/10.15345/iojes.2021.02.010
} 
Keywords:

Mathematics course and teacher perception, mathematics course achievement, psychoeducational program, cognitive-behavioral approach.

\section{Introduction}

The main purpose of the education system is to ensure that students gain the desired behaviors. One of the final goals expected from every student attending school is to become successful in the academic sense. Student success can be defined as progress made by the student in achieving the targeted results according to his/her school, class, and course, while failure can be defined as a difference between the existing ability and success at school (Ar1, 2007). When the literature is reviewed, it is observed that many factors have an effect on student success or failure in education and training activities (Ergün, Özdemir and Çorlu, 2004). In student success, factors related to the student himself/herself, factors originating from the family, teacher and school may be effective in a basic sense. Especially students' perceptions of the course and the teacher of the course, which are among the affective characteristics of students, significantly affect their academic achievement (Arıc1, 2007).

While students express their perceptions of the course they have failed, they can reveal both their knowledge of that course and their experiences and the meanings they attribute to these experiences. Attitude, which is a basic psychological concept that guides human perception, consists of cognitive, affective, and behavioral elements. Therefore, attitude can shape the individual's point of view, feelings, and behavior on a subject. While students' interest in learning, curiosity, desires, and positive attitudes towards the course and teacher increase their school achievement, students' disinterest in learning, the lack of goals, negative attitudes and behaviors towards the course and teacher can also reduce their school achievement. The studies reveal that a positive attitude towards a course is an important factor in the realization of learning (Bölükbaş, 2004; Karasakaloğlu and Saracaloğlu, 2009; Saracaloğlu, 2000; She and Fisher, 2002). A student who has a positive attitude towards a course or subject motivates himself/herself internally in the learning process, which can facilitate the students' learning of that course in this case. The student's success in a course and his/her perceptions of this success can increase the student's determination in success and self-confidence (Bloom, 1979). Therefore, the student's attitude towards the course and positive perceptions of himself/herself affect his/her success.

Mathematics is one of the courses in which affective characteristics significantly affect the learningteaching process. While students' beliefs in that they can become successful in mathematics and their positive feelings towards the mathematics course contribute to increasing their course achievement (Yücel and Koç, 2011), students' negative feelings towards the mathematics course may cause them to fail this course (Çoban, 1989). The qualities of the interaction of the teacher of the course with students are effective in the formation of students' own perceptions of success. The fact that teachers are loving and sincere towards students inside and outside the course, can establish a comfortable and close relationship with them and, accordingly, exhibit positive attitudes plays a role in the formation of students' perceptions of success. Although the teacher has generally accepted behaviors in the classroom, some students may perceive it differently. Students' inability to establish a positive interaction with their teacher may cause them to develop a negative perception of the course and the teacher of the course, and because of this negative perception, students' interest in the course and learning motivation decrease, which may lead to a decrease in course achievement.

This study is important for the effectiveness of the perception of the course and the teacher of the course, which is one of the factors affecting the student's mathematics course achievement, on the student's course achievement, and conducting the necessary studies. It was observed that studies investigating the factors affecting student's course achievement (An1l, 2009; Karaarslan, 2010; Sar1er, 2016), the effect of teacher 
effectiveness on student success (Heck, 2009), and the relationship between the attitude towards mathematics course and the success (Mirasyedioğlu and Peker, 2003) were conducted in the literature. When the literature is reviewed, it is observed that the presence of a positive relationship between academic course achievement and efficient course studying habits is a common result of many studies (Babaoğlan, 2017; Bıyıklı, 2017; Yörük, 2007). Furthermore, there are studies showing that the cognitive-behavioral approach-based psycho-education programs given to students have positive effects on efficient course studying skills, exam anxiety, and academic achievement (Subaşı, 2000; Bozanoğlu, 2005; Demirci and Erden, 2016). However, it is observed that these studies are the investigations that addressed the factors affecting the success separately. In fact, it is known that there are many factors that affect the success and are related to each other. It can be said that the most important ones of these factors are efficient course studying behaviors and the perception of the course and the teacher of the course. It is considered important to study these factors by discussing them together. In the literature, it was observed that there was no planned psycho-education program in which the follow-up study of efficient course studying behaviors that can be applied to high school students and the study on changing the negative perceptions of the mathematics course and the teacher were discussed together.

Therefore, the examination of whether the cognitive-behavioral approach-based psycho-education program supported by the follow-up study of the behaviors of efficient course studying given to tenth-grade students who have failed the mathematics course and have a negative perception of the mathematics course and teacher has an effect on students' attitudes towards the mathematics course achievement and the mathematics course and teacher constitutes the aim of this study. In line with this aim, the following hypotheses were tested.

1.The psycho-education program applied has a positive effect on students' mathematics course achievement.

2.The psycho-education program applied has a positive effect on students' attitudes towards the mathematics course.

3.The psycho-education program applied has a positive effect on students' attitudes towards the mathematics course teacher.

\section{Method}

The research was conducted with a quasi-experimental model with a matched control group for the pretest and post-test mathematics course achievement.

\section{Study Group}

The study group consisted of a total of 30 tenth-grade students, including 16 female and 14 male students, studying in an official academic high school in Adana. Teachers' opinions, individual interviews conducted with students, and the mean $1^{\text {st }}$ and $2^{\text {nd }}$ written exam scores (excluding performance scores) for the

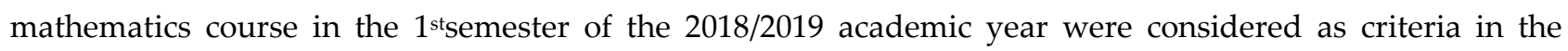
selection of experimental and control group students. A total of 30 students, including 16 female and 14 male students, were selected from among 36 students whose mathematics course achievement score range was between 22 and 42, and the experimental and control groups were formed by subject matching for the mean mathematics course achievement scores. The experimental and control groups consisted of 15 students, eight girls and seven boys each.

\section{Data Collection Tools}

The Attitude Towards the Mathematics Course Scale and the Attitude Towards the Teacher Scale were used in the study. The results of the tests prepared by the teacher to measure the course achievement were used as the measurement of the mathematics course achievement. 


\section{Attitude Towards the Mathematics Course Scale}

The Attitude Towards the Mathematics Course Scale was developed by Çermik, Güner, and Yaşar (2014) to measure the attitudes of students studying in high schools in Turkey towards the mathematics course. This scale consists of 35 items with positively and negatively formulated five-point Likert-type response options. The lowest and highest scores that can be obtained from the scale are 35 and 175 , respectively.

This tool consists of four sub-dimensions, including enjoyment, fear, anxiety and distress, the place of Mathematics in life, its importance, and the perceived academic achievement. The scale can be used as a total score. The Cronbach alpha reliability coefficient of the scale was found to be 0.94 .

It was observed that the item-total score correlation values of the scale ranged between 0.33 and 0.85 with the students $(\mathrm{N}=241)$ at the school, which included the study group with whom this study was conducted, and that the Cronbach alpha internal consistency coefficient was 0.97 .

\section{Attitude Towards the Teacher Scale}

This scale was developed as the attitude towards the Primary School Religious Culture and Moral Knowledge course scale for $6^{\text {thand }} 7^{\text {th }}$-grade students (Aric1, 2007). In practice, the scale can be used to measure the attitudes towards different course teachers by changing the directive of the scale in line with the purpose of the application. This scale consists of 19 items with positively and negatively formulated five-point Likerttype response options. The lowest and highest scores obtained from the scale are 19 and 95, respectively. The scale items are in a single factor with factor load values between 0.52 and 0.76 and explaining $46 \%$ of the variance. The item-total correlations of the scale ranged between 0.48 and 0.72 . The Cronbach alpha internal consistency coefficient was calculated as 0.93 .

It was found that the item-total score correlation values of the scale ranged between 0.30 and 0.79 with the students $(\mathrm{N}=241)$ at the school, which included the study group with whom this study was conducted, and that the Cronbach alpha internal consistency coefficient was 0.90 .

\section{Measurement of the Mathematics Course Achievement}

The mean scores of the $1^{\text {st }}$ and $2^{\text {nd }}$ written exams conducted by the teacher for the mathematics course in the $1^{\text {st }}$ semester of the 2018/2019 academic year (excluding performance scores) were considered as the measurement of the pre-test achievement scores, and the scores of the $1^{\text {st }}$ written exam conducted in the $2^{\text {nd }}$ semester of the same academic year were considered as the measurement of the post-test achievement scores. The scores of the $2^{\text {nd }}$ exam achievement in the $2^{\text {nd }}$ semester were considered as the follow-up measurement.

\section{Procedure}

When developing a psycho-education program based on cognitive behavioral approach the first assumptions of cognitive behavioral approach that are derived from the idea that ones' thought structure, perception and interpretation of events affect his/her emotions and behavior are considered and the methods and techniques of this approach that aim to work on unrealistic and disfunctional beliefs and change these beliefs with rational and realistic ones are examined (Ellis, 1973, 1993). In addition, structured group guidance programs that are based on cognitive behavioral approach, and the literature on negative perception/attitude towards the course and the teacher of the course were first reviewed while developing the cognitivebehavioral approach-based psycho-education program. As a result of the literature review, an eight-session program, including issues related to cognitive-behavioral approach-based achievement, perception, mathematics course achievement, perceptions of the mathematics course and teacher, and attributional styles, was prepared. 
The pilot study for the content of the program prepared was conducted with a total of 15 eleventh-grade students, including eight female and seven male students, in an official academic high school in the city center of Adana in the 2017/2018 academic year. The pilot study for the content of the program was conducted with a total of eight sessions, with a duration of 50 minutes and one session per week. In addition to the program prepared as a result of the observations and evaluations on the pilot study, it was considered appropriate to study in more detail with attributional styles and to perform the follow-up study of efficient course studying behaviors.

After the shortcomings in the psycho-education program were eliminated, the pilot study for the applicationwas conducted with a total of 15 tenth-grade students, including eight female and seven male students, in the high school, where the first pilot study was conducted, in the first semester of the 2018/2019 academic year. The pilot study for the application of the program was conducted in a total of eight sessions, one session per week (50 minutes), as in the pilot study for the content. Furthermore, apart from the psychoeducation program, gatherings were conducted to review the efficient course studying behaviors and to follow up the studying behaviors in small groups (3-4 students) for 30-40 minutes for eight weeks, one session per week, outside the day and time of the application in order to follow up students' course studying behaviors and to provide feedback.

\section{Application of the Psycho-education Program}

\section{Cognitive-Behavioral Approach-Based Application}

In the sessions of the psycho-education program, the process was structured in the first session, and the process was evaluated and terminated in the last session. In the sessions between the $2^{\text {nd }}$ and $7^{\text {th }}$ sessions, the process progressed by summarizing the previous session, sharing of members' experiences after the previous session, evaluating homework assignments, applying the session content of that day and summarizing the session, and getting members' feelings and thoughts about the session. The psycho-education program was applied in a total of eight sessions, one session per week, and it was studied for 50 minutes in each session, as in the pilot studies for the content and application. The way the sessions were conducted is summarized below.

In the first session, the members of the group were allowed to meet each other and group leaders, and then, information was given about the group goals and rules. Furthermore, members were informed about the methods to be used in the group process and the importance of homework assignments.

In the second session, the definition of achievement was studied with the group members, and it was focused on the short and long-term importance of mathematics course achievement in the school achievement of the members. It was ensured that the members shared the reasons for the failure in the mathematics course with the group, and they were asked to think about the reasons for the failure in the mathematics course and to evaluate their effect levels on their failure as a homework assignment until the next session.

In the third session, it was observed that the members' reasons for the failure in the mathematics course were negative perception towards the course, one of the individual factors, and accordingly, the inability to exhibit efficient course studying behaviors. Furthermore, it was determined that students' negative perceptions of the teacher of the course (such as dislike of the teacher, teacher's low marks, lack of selfconfidence) were effective on the failure. In this session, research was conducted on the definition of perception, the effect and importance of perception in learning the mathematics course content, and also the factors affecting students' perceptions.

In the fourth and fifth sessions, sample cases on the mathematics course and the teacher of the course (such as, I got a low mark in the mathematics course, my course performance is low, I am very successful in the mathematics course; I cannot communicate with the mathematics teacher, he/she dislikes me, gives me 
low marks, or he/she is my favorite teacher) were shared with the members, and it was attempted to teach the members to detect their automatic thoughts about the negative perception. The ABC model, which is a thought regulation technique, was explained to the members, and the members were allowed to recognize and question their irrational beliefs about the sample cases shared.

In the sixth session, the members were allowed to share their evaluations about themselves in the Thought Record Forms related to the negative perception of the mathematics course and the teacher of the course given as a homework assignment in the fourth and fifth sessions. The $\mathrm{D}$ (disputing) $\mathrm{E}$ (effect) $\mathrm{F}$ (feeling) system was explained to the members, and the members were allowed to refute irrational beliefs and to recognize the effect of this refutation, and the new feeling emerged.

In the seventh session, the attributional style in school achievement was studied with the members, and the members were allowed to share their attributional profiles (ability, efficient course studying, effort, easiness of the course, luck, like of the teacher) with the group members.

In the eighth session, the program was summarized with a few sentences from the first session to the last session. For each member, the positive changes observed in them from the beginning to the end of the program were shared, and it was stated to be important that the positive changes observed in the members were functional in school life.

\section{Application of the Follow-up of Efficient Course Studying Behaviors}

Apart from the cognitive-behavioral approach-based application, informative studies were conducted on the follow-up of efficient course studying behaviors given to students in small groups in the form of one session per week (30-40 minutes). In the first session, information was obtained from the members about how they studied, and based on this information, it was found out that most of the students did not perform their studies regularly and consistently. It was focused on the members' reasons for irregular and unplanned course studying, and solution proposals were discussed.

In the second study, the efficient course studying behaviors of the members were reviewed, the members were informed about efficient course studying methods, and they were guided in the preparation of course studying programs.

In the third study, the application checklist was applied to the members' efficient course studying methods, and they were followed up.

In the fourth study, the members' repetition and problem-solving charts and course attendance behaviors were checked, and consequently, it was observed that most of the members had positive developments.

In the fifth and sixth studies, the members were allowed to perform self-evaluation on their efficient course studying behaviors, and it was focused on the feedback about their achievement status received from teachers. It was observed that there were positive developments in the efficient course studying behaviors of the members.

In the seventh and final study, it was observed that the members prepared for the mathematics written exam to be conducted at school efficiently and had positive statements that they would be successful in the mathematics course.

\section{Data Collection}

For the application part of the study, written permissions were first obtained to conduct the study in an official academic high school affiliated to the Ministry of National Education (MoNE) in the city center of Adana. The Attitude Towards the Mathematics Course Scale and the Attitude Towards the Teacher Scale were 
applied to the students in the experimental and control groups before starting the first session, the pre-test was applied on the same day, and the post-test was applied after the last session was over, and the follow-up measurement was performed six weeks after the application was over. For the mathematics course achievement, while students' 1st and 2nd written exam scores for the mathematics course in the 1st semester of the 2018/2019 academic year were considered as the pre-test measurement, their 1st written exam scores for the mathematics course in the 2nd semester were considered as the post-test measurement, and their 2nd written exam scores for the mathematics course in the 2nd semester of the same academic year were considered as the follow-up measurement.

\section{Data Analysis}

The data collected were analyzed using the SPSS 22.0 statistical package program. It was concluded that the Kolmogorov Smirnov- $Z$ values of the mathematics course achievement, attitude towards the mathematics course and attitude towards the teacher pre-test and post-test scores of the experimental and control groups varied between 0.10 and 0.21 ( $p>0.05$ ) and that the measurements met the normality assumption for all analysis units based on this result. When the mathematics course achievement, and attitudes towards the course and the teacher pre-test scores of the experimental and control groups were compared, it was observed that there was no significant difference ( $p>0.05)$ between the mathematics course achievement $(t=0.16)$ and attitudes towards the course $(t=1.74)$ and that there was a significant difference in attitudes towards the teacher scores in favor of the control group $(\mathrm{t}=2.34 ; \mathrm{p}<0.05)$. Based on these results, in the analysis of whether the experimental process had a significant effect on the dependent variables, the $2 \times 2$ mixed-design analysis of variance was used for the measurements of the mathematics course achievement and the attitudes towards the course, and the covariance analysis technique, in which pre-test scores were included in the analysis as a covariate, was used in the analysis of the attitudes towards the teacher scores. In the follow-up study, the comparison of three measurements of the experimental and control groups was performed by the variance analysis technique for one-factor repeated measurements. The level of significance was considered as 0.05 in the interpretation of the results.

\section{Results}

The results achieved in the analysis of the hypotheses established in line with the aim of the study are discussed below, respectively.

\section{Results on the Mathematics Course Achievement}

The descriptive values of the pre-test, post-test, and follow-up scores regarding the mathematics course achievement of the students in the experimental and control groups, and the results of the $2 \times 2$ mixed-design analysis of variance are presented in Table 1.

Table 1. Descriptive Values of the Pre-test, Post-test, and Follow-up Scores Regarding the Mathematics Course Achievement of the Experimental and Control Groups and the Results of the Analysis of Variance

\begin{tabular}{|c|c|c|c|c|c|c|c|}
\hline \multirow[b]{2}{*}{ Group } & \multirow[b]{2}{*}{$\mathbf{n}$} & \multirow[b]{2}{*}{ Measurements } & \multirow[b]{2}{*}{$\mathbf{M}$} & \multirow[b]{2}{*}{ Sd } & \multicolumn{3}{|c|}{$\mathbf{F}$} \\
\hline & & & & & Group & Measurement & Group $\times$ Measurement \\
\hline \multirow{3}{*}{ Experiment } & \multirow{3}{*}{15} & Pre-test & 32,53 & 5,84 & & & \\
\hline & & Post-test & 48,07 & 15,97 & $5,55^{*}$ & $7,84^{*}$ & $5,70^{*}$ \\
\hline & & Follow-up & 55,87 & 3,34 & & & \\
\hline \multirow{3}{*}{ Control } & \multirow{3}{*}{15} & Pre-test & 32,57 & 5,71 & & & \\
\hline & & Post-test & 33,80 & 14,86 & & & \\
\hline & & Follow up & 39,07 & 15,70 & & & \\
\hline
\end{tabular}

${ }^{*} \mathrm{p}<0,05$ 
As a result of the analysis, it was found that the group ( $\mathrm{F}=5.55)$, measurement $(\mathrm{F}=7.84)$ main effects and group $\times$ measurement $(\mathrm{F}=5.70)$ common effect were significant $(\mathrm{p}<0.05)$. When the direction of the group $\times$ measurement common effect was examined, it was observed that this effect was in favor of the posttest scores of the experimental group. As a result of the analysis of variance for repeated measurements performed to examine the permanence of this change in the experimental group, it was concluded that posttest and follow-up measurement scores were higher than pre-test scores $(\mathrm{F}=10.98 ; \mathrm{p}<0.01)$. This result showed that the change was permanent. No significant difference was found in the control group measurements $(\mathrm{F}=1.14 ; \mathrm{p}>0.01)$. These results confirmed the hypothesis "The psycho-education program applied has a positive effect on students' mathematics course achievement" of the study.

\section{Results on the Attitude Towards the Mathematics Course}

The descriptive values of the pre-test, post-test, and follow-up scores regarding the attitude towards the mathematics course of the students in the experimental and control groups, and the results of the $2 \times 2$ mixeddesign analysis of variance are presented in Table 2.

Table 2. Descriptive Values of the Pre-test, Post-test, and Follow-up Scores Regarding the Attitude Towards the Mathematics Course of the Experimental and Control groups and the Results of the Analysis of Variance

\begin{tabular}{|c|c|c|c|c|c|c|c|}
\hline \multirow[b]{2}{*}{ Group } & \multirow[b]{2}{*}{$\mathbf{n}$} & \multirow[b]{2}{*}{ Measurements } & \multirow[b]{2}{*}{$\mathbf{M}$} & \multirow[b]{2}{*}{ Sd } & \multicolumn{3}{|c|}{$\mathbf{F}$} \\
\hline & & & & & Group & Measurement & Group $\times$ Measurement \\
\hline \multirow{3}{*}{ Experiment } & \multirow{3}{*}{15} & Pre-test & 87,47 & 11,29 & \multirow{3}{*}{$4,46^{*}$} & \multirow{3}{*}{$307,83^{*}$} & \multirow{3}{*}{$320,63^{*}$} \\
\hline & & Post-test & 126,73 & 10,90 & & & \\
\hline & & Follow up & 130,93 & 10,67 & & & \\
\hline \multirow{3}{*}{ Control } & \multirow{3}{*}{15} & Pre-test & 96,53 & 16,79 & & & \\
\hline & & Post-test & 96,13 & 16,98 & & & \\
\hline & & Follow-up & 96,60 & 11,31 & & & \\
\hline
\end{tabular}

${ }^{*} \mathrm{p}<0,05$

As a result of the analysis, it was found that the group ( $\mathrm{F}=4.46)$, measurement ( $\mathrm{F}=307.83$ ) main effects and group $\times$ measurement $(\mathrm{F}=320.63)$ common effect were significant $(\mathrm{p}<0.05)$. When the direction of the group $\times$ measurement common effect was examined, it was observed that this effect was in favor of the posttest scores of the experimental group. As a result of the analysis of variance for repeated measurements performed to examine the permanence of the change, it was concluded that the post-test and follow-up measurement scores of the experimental group were higher than pre-test scores. Therefore, the change was permanent $(\mathrm{F}=176.00 ; \mathrm{p}<0.01)$. No significant difference was found in the control group measurements $(\mathrm{F}=0.12$; $\mathrm{p}>0.01$ ). These results achieved confirmed the hypothesis,"The psycho-education program applied has a positive effect on students' attitudes towards the mathematics course." of the study.

\section{Results on the Attitude Towards the Teacher}

The descriptive values of the pre-test, post-test, and follow-up scores regarding the attitude towards the mathematics course teacher of the students in the experimental and control groups and the results of the covariance analysis are presented in Table 3.

Table 3. Descriptive Values of the Pre-test, Post-test, and Follow-up Scores Regarding the Attitude Towards the Mathematics Course Teacher of the Experimental and Control Groups and the Results of the Covariance Analysis

\begin{tabular}{|c|c|c|c|c|c|c|}
\hline Group & $\mathbf{n}$ & Measurements & $\mathbf{M}$ & Sd & Corrected M & $\mathbf{F}$ \\
\hline \multirow{3}{*}{ Experiment } & \multirow{3}{*}{15} & Pre-test & 59,33 & 9,11 & \multirow{3}{*}{81,90} & \multirow{3}{*}{$207,19^{*}$} \\
\hline & & Post-test & 79,67 & 7,24 & & \\
\hline & & Follow up & 82,80 & 8,29 & & \\
\hline Control & 15 & Pre-test & 65,73 & 5,19 & 63,23 & \\
\hline
\end{tabular}




$\begin{array}{lll}\text { Post-test } & 65,47 & 4,63 \\ \text { Follow-up } & 66,33 & 4,45\end{array}$

${ }^{*} \mathrm{p}<0,05$

When the pre-test scores for the teacher of the students in the experimental and control groups were included in the analysis as a covariate, it was found that there was a significant difference between the corrected post-test mean scores of the experimental ( $\bar{x}=81.90)$ and control ( $\bar{x}=63.23)$ groups in favor of the experimental group $(\mathrm{F}=207.19 ; \mathrm{p}<0.05)$. As a result of the analysis performed to examine the permanence of the change, it was found that the attitude change towards the mathematics course teacher in the experimental group was permanent $(\mathrm{F}=158.70 ; \mathrm{p}<0.01)$. No significant difference was observed between the mean scores in the control group $(\mathrm{F}=0.54 ; \mathrm{p}>0.01)$. These results achieved showed that the hypothesis" The psycho-education program applied has a positive effect on students' attitudes towards the mathematics course teacher." was confirmed.

\section{Comments and Discussion}

In this study, as a result of the psycho-education program supported by the follow-up study for reviewing and controlling the course studying behaviors given to the experimental group students who had negative perceptions towards the mathematics course and teacher, it was determined that the mathematics course achievement scores of the experimental group students increased in comparison with the control group students to whom the education was not given. Furthermore, at the end of the study, it was found that students' attitudes towards the mathematics course and teacher were also positively affected.

Along with the cognitive-behavioral approach-based psycho-education program, the follow-up study for reviewing and controlling the efficient course studying skills had positive effects on the mathematics course achievement in the students. In the study conducted by Kaya (2001), as a result of the group guidance program provided to high school students to gain efficient course studying habits, it was observed that course achievement increased in the experimental group students compared to the control group students. Furthermore, it is observed that this result of the study is parallel with the common result of many studies indicating a positive relationship between academic course achievement and efficient course studying habits (Babaoğlan, 2017; Bıyıklı, 2017; Yörük, 2007).

It was observed that the cognitive-behavioral approach-based psycho-education program given to the experimental group students affected the change in the students' negative perceptions of the course and the teacher. It is also observed in similar studies that the programs given to students based on the cognitivebehavioral approach have a positive effect on efficient course studying skills, exam anxiety, and the increase in academic achievement (Subaşı, 2000; Bozanoğlu, 2005; Demirci and Erden, 2016).

According to the results of the study, it can be said that there were positive relationships between students' attitudes towards the mathematics course and the teacher of the course and the course achievement. It has been revealed by many research results that there is a positive relationship between the mathematics course achievement and the attitude towards the mathematics course (Sezgin, 2007), that high school students' negative perceptions of the mathematics course negatively affect the course achievement (Balk1 et al., 2009) and that the perception of learning and course studying strategies (Bilasa, 2016) and teacher attitudes (Şerefli, 2003; Koç, Öztürk and Şahin, 2003) are associated with the course achievement of students. Furthermore, in many studies on this subject, it was concluded that there was a mutual relationship between attitudes and achievement (Tekindal, 1988; Baykul, 1990; Berberoğlu, 1990; Saracaloğlu, 2000; Savaş and Duru, 2005).In the study, based on most of the students' statements such as "the mathematics course is important, it is a course I can achieve when I study, I have started to attend the course" after the fifth session in the psycho-education program given to the experimental group students, it was observed that their attitudes started to change positively as their studies for the mathematics course and their attendance in the course increased. In the study 
carried out byÖzlü (2001), the result indicating that students' attitudes towards the mathematics course are related to the perceived mathematics course achievement is parallel with the results of this study.

In the psycho-education program applied in the study, the students stated that they attended the course more effectively and that the teachers gave them positive feedback in this direction. It can be said that teachers' attitudes and behaviors towards students affect students' perception of the teacher and the course and that the fact that the teacher trusted students, cared about them and exhibited supportive attitudes for achievement contributed to the development of positive perceptions of the course and the teacher of the course in the experimental group students. This view is also supported by the results of the relevant studies (Yıldırım, 2000; Günay, 2003).

According to the results of the study, students' attitudes and perceptions of the teacher of the course were related to the relevant course achievement and that there was a further increase in interest in the course as positive attitudes and perceptions of the teacher developed, which could be effective in applying efficient course studying methods. In the literature, it is observed that there is a strong positive relationship between the mathematics course achievement and the dimensions of supportive teacher behaviors of the school climate and success orientation (Giorgettı and Bahçetepe, 2015). Accordingly, the fact that the teacher behaviors perceived by students are related to success can be said to be in line with the results of this study.

One of the limitations of this study was that the family and teacher factors affecting student success and student's perception of the course and the teacher were not studied in the study. Another limitation of the study was that only the attitudes towards the course and the teacher of the course and the follow-up of course studying skills were discussed in the academic achievement of the student. However, in addition to these factors, it can be said that factors such as the learning environment, methods and techniques used by the teacher, friends, family, studying environment at home, and perceived social support may also play a role in academic achievement. Furthermore, although the validity and reliability of the tests that were used to measure the success of students in the study are controversial, they were the tests that teachers prepared to measure the success in the teaching process and used in exams. Although these exam scores used for achievement measurement are considered to have a limitation for the internal validity of the result achieved in the study, it can also be said that it makes the external validity of the result stronger.

\section{Conclusion and Recommendations}

In the study in which the cognitive-behavioral approach-based psycho-education program supported by the follow-up study of the course studying behaviors was given, it was concluded that this education also had a positive effect on students' mathematics course achievement and their attitudes towards the mathematics course and the teacher of the course.

In accordance with the results of this study, psychological counselors working in high school can apply this program to students who have failed the course and have a negative perception of the course and the teacher of the courses. Teachers can be provided with education to make them understand the effectiveness of their attitudes towards students. School counseling services can conduct psycho-education program studies for students at different grade levels who have failed the course or have negative perceptions of the course and the teacher of the course, and according to the course needed. Studies aimed at gaining, developing, and following up efficient course studying skills can be conducted for students in accordance with their needs, and cooperation can be made with parents to ensure the permanence of these behaviors and follow-up in the home environment. In this study, attitudes towards the course and the teacher of the course, which affect students' course achievement, and the role of following up efficient course studying behaviors were studied. In future studies, the effects of the variables that play a role in the course achievement and students' perceptions and attitudes, such as the family's role, teacher attitudes, teaching methods and techniques, ability, mother and 
International Online Journal of Educational Sciences, 2021, 13 (7), 478-491

father's educational level, studying environment at home, teachers' perceptions of unsuccessful students, level of readiness, perceived social support, and self-efficacy belief, can also be examined with experimental studies. 


\section{REFERENCE}

Anıl, D. (2009). Uluslararası Öğrenci Başarılarını Değerlendirme Programı (PISA)'nda Türkiye'deki öğrencilerin fen bilimleri başarılarını etkileyen faktörler. Ĕ̆itim ve Bilim, 152 (34), 87-100.

Arı, A. (2007). Öğrencilerin okul başarılarını etkileyen çeşitli faktörlerin incelenmesi. Milli Ĕ̆itim Dergisi. 176, 169-179.

Arıcı, İ. (2007). İlköğretim Din Kültürü ve Ahlak Bilgisi Dersinde Öğrenci Başarısını Etkileyen Faktörler - Ankara Örneği. Ankara Üniversitesi Sosyal Bilimler Enstitüsü Felsefe ve Din Bilimleri (Din Eğitimi) Anabilim Dalı, Yayınlanmamış Doktora Tezi, Ankara.

Babaoğlan, E. (2017). Yozgat'ta öğrenci başarısı: Başarı engelleri ve başarıyı artırmak için yapılabilecekler. Mustafa Kemal Üniversitesi Sosyal Bilimler Enstitüsü Dergisi, 14(37), 23-40.

Balkı, N., Dane, A. ve Kudu, M. (2009). Lise öğrencilerinin algılarına göre, matematik başarısını olumsuz yönde etkileyen faktörler. EÜFBED - Fen Bilimleri Enstitüsü Dergisi, 2-1, 17-34.

Baykul Y. (1990). Matematikle ilgili düşünceler anketi. Ankara: ÖSYM Yayınları.

Berberoğlu, G. (1990). Kimyaya ilişkin tutumların ölçülmesi. Eğitim ve Bilim, 76, $16-27$.

Bıyıklı, C. (2017). Ortaokul öğrencilerinin Türkçe dersi akademik başarıları ile ders çalışma alışkanlıkları arasındaki ilişki. Pamukkale Üniversitesi Ĕ̆itim Fakültesi Dergisi, 42 (2), 59-73.

Bilasa, P. (2016). Ortaöğretim öğrencilerinin öğrenme ve ders çalışma stratejilerinin çeşitli değişkenler açısından incelenmesi (Ankara Hacı Ömer Tarman Anadolu Lisesi Örneği). YYÜ Eğitim Fakültesi Dergisi(YYU Journal Of Education Faculty), XIII(I),79-122

Bloom, B. S. (1979). Human Characteristics and School Learning. New York: McGraw-HillInc., 1976 İnsan Nitelikleri ve Okulda öğrenme. Çeviren: Durmuş Ali Özçelik. Ankara: Milli Eğitim Basımevi.

Bozanoğlu, İ. (2005). Bilişsel davranışçı yaklaşıma dayalı psiko-eğitim programınin güdülenme, benlik saygısı, başarı ve sınav kaygısı düzeylerine etkisi. Ankara Üniversitesi Eğitim Bilimleri Fakültesi Dergisi, 38(1), $17-42$

Bölükbaş, F. (2004). Yansıtıcı öğretimin ilköğretim ikinci kademe öğrencilerinin türkçe dersine yönelik tutum ve başarıları üzerindeki etkililiği. Yayımlanmamış Doktora Tezi, DEÜ Eğitim Bilimleri Enstitüsü, İzmir.

Çermik, H., Güner, N., Yaşar, M. (2014). Türkiye'deki lise öğrencilerinin matematik dersine ilişkin tutumları ve bu tutumlarını etkileyen faktörler. Ankara Üniversitesi Ĕgitim Bilimleri Fakültesi Dergisi, 47 (2) , 41-64.

Çoban A. (1989). Ankara merkez ortaokullarındaki son sını öğrencilerinin matematik dersine ilişkin tutumları. Yayınlanmamış Yüksek Lisans Tezi, Gazi Üniversitesi Sosyal Bilimler Enstitüsü, Ankara.

Ellis, A. (1973). Humanistic psycho therapy therational-emotive approach. (Ed. Edward Sagarin) New York: The Institute for Rational Living, Inc.

Ellis, A. (1993). Fundamentals of rational-emotive therapy for the 1990s. W. Dryden\& L. K. Hill (Ed.), Innovations in rational emotive therapy (1-32). Newbury Park: Sage Publications.

Erden, S. ve Demirci, İ. (2016). Bilişsel davranışçı yaklaşıma dayalı grupla psikolojik danışma uygulamasının 8. sınıf öğrencilerinin sınav kaygısına etkisi. Marmara Üniversitesi Atatürk Eğitim Fakültesi Eğitim Bilimleri Dergisi 43, 67-83.

Ergün, H. Özdemir, M. Çorlu, M. A. (2004). Dil ve sayısal yetenekler ile fizik başarısı arasındaki ilişki. Kastamonu Eğitim Dergisi, 12, (2), 361-368. 
Gıorgettı, M. F. ve Bahçetepe, Ü. (2015). Akademik başarı ile okul iklimi arasındaki ilişki. İstanbul Journal of Innovation in Education.3, (1), 83-101.

Günay, K. (2003). Sınıf yönetiminde öğretmenlerin iletişim becerilerinin değerlendirilmesi. Yayımlanmamış Yüksek Lisans Tezi, Çukurova Üniversitesi Sosyal Bilimler Enstitüsü, Adana.

Heck, R. H. (2009). Teacher effectiveness and student achievement: Investigating a multi level cross-classified model. Journal of Educational Administration, 47(2), 227-249.

Karaarslan, G. (2010). Orta öğretim kurumlarında öğrenci başarısını etkileyen faktörlerin istatistiksel analizi. Yayınlanmamış Yüksek Lisans Tezi, İstanbul Teknik Üniversitesi Fen Bilimleri Enstitüsü, İstanbul.

Karasakaloğlu, N. ve Saracaloğlu, A.S. (2009). Sınıf öğretmeni adaylarının türkçe dersine yönelik tutumları, akademik benlik tasarımları ile başarıları arasındaki ilişki. Yüzüncü Yıl Üniversitesi Ĕ̆itim Fakültesi Dergisi, 6 (1), 343-362.

Kaya, M. (2001). Lise 1. sınıf öğrencilerine verimli çalışma alışkanlıkları kazandırmada psiko-eğitim programının etkisi. Yayınlanmamış Yüksek Lisans Tezi, İnönü Üniversitesi Sosyal Bilimler Enstitüsü, Malatya.

Mirasyedioğlu, Ş. ve Peker, M., (2003). Lise 2. sınıf öğrencilerinin matematik dersine yönelik tutumları ve başarıları arasındaki ilişki. Pamukkale Üniversitesi Ĕ̆itim Fakültesi Dergisi, 14, (2), 157-166.

Özlü, Ö. (2001). Ortä̈ğretim öğrencilerinin matematiğe karşı tutumları. Yayınlanmamış Yüksek Lisans Tezi, Marmara Üniversitesi, Fen Bilimleri Enstitüsü, İstanbul.

Öztürk, B; Koç, G. ve Şahin, F.T. (2003). Sınıf öğretmenlerinin öğrencileri arasında ayırım yapma durumu ve bu ayırımın bazı değişkenler açısından incelenmesi. Türk Ĕ̆itim Bilimleri Dergisi. 1 (1), 109-120.

Savaş, E., Taş, S., \& Duru, A. (2010). Factors affecting students'achivement in mathematics'. İnönü University Journal of Faculty of Education, 11, 113-132.

Saracaloğlu, A.S. (2000). Öğretmen adaylarının yabancı dile yönelik tutumları ile akademik başarıları arasındaki ilişki. Ĕ̆itim ve Bilim 25 (115), 65-72.

Sarıer, Y. (2016). Türkiye'de öğrencilerin akademik başarısını etkileyen faktörler: Bir meta-analiz çalışması. Hacettepe Üniversitesi Ĕ̆itim Fakültesi Dergisi, 31 (3), 609-627.

Sezgin, M. (2007).Öğrencilerinin matematik başarısına etki eden faktörler (10. Sinıf Örneği). Yayımlanmamış Yüksek Lisans Tezi, Beykent Üniversitesi Sosyal Bilimler Enstitüsü, İstanbul.

She, H. C., Fisher, D. (2002). Teacher communication behavior and its association with students. Cognitive and attitudinal out comes in science in Taiwan. Journal of Research in Science Teaching, 39 (1), 63-78.

Subaşı, G. (2000). Verimli ders çalışma alışkanlıkları eğitiminin, akademik başarı, akademik benlik kavramı ve çalışma alışkanlıklarına etkisi. Ĕ̆itim ve Bilim, 117, 50-56.

Şerefli, K.A. (2003). İlköğretim ikinci kademe öğrencilerinin akademik başarılarını etkileyen zihinsel olmayan faktörler. Yayımlanmamış Yüksek Lisans Tezi, Niğde Üniversitesi Sosyal Bilimler Enstitüsü.

Tekindal, S. (1988). Okula ilişkin tutum ile akademik başarı arasındaki ilişki. Çă̆daş Ĕ̆itim, 139, 29-33.

Yıldırım, İ. (2000). Akademik başarının yordayıcısı olarak yalnızlık, sınav kaygısı ve sosyal destek. Hacettepe Üniversitesi Ĕ̆itim Fakültesi Dergisi, 18, 167-176.

Yörük, D. (2007). Lise öğrencilerinin akademik başarıları, başarı korkuları ve verimli ders çalışma alı̧̧kanlıkları arasındaki ilişkilerin incelenmesi. Yayınlanmış Yüksek Lisans Tezi, Gazi Üniversitesi Sosyal Bilimler Enstitüsü, Ankara. 
Yücel, Z. ve Koç, M. (2011). İlköğretim öğrencilerinin matematik dersine karşı tutumlarının başarı düzeylerini yordama gücü ile cinsiyet arasındaki ilişki. Illköğretim Online, 10(1), 133-143. 